\title{
Oriental Discourse in Russia: The Case of Alexander Pushkin
}

\author{
Marina Apaydin (MsEE, MBA, MA, PhD) \\ American University of Beirut, Lebanon
}

URL:http://dx.doi.org/10.19044/llc.v6no1a1

\begin{abstract}
This paper takes a holistic view of the phenomenon of Oriental discourse in the Russian literary tradition in an attempt to understand its roots, connections and historical and literary evolution during the past three centuries. Although Russian Oriental discourse started and was inspired by German Romanticism, and the French Enlightenment, that discourse soon afterwards grew into a totally independent phenomenon (which I call 'Orientalearning') of 'naturalization' of the oriental texts, appropriating their ideas and literary characters but providing them with a new Russian meaning. As a result, Russian Vostokian naturalizations have become an inseparable part of the native Russian literary tradition since the 19th century. To illustrate this phenomenon, a number of examples of adaptation of early pre-modern Arabic texts into Russian are analyzed, including Alexander Pushkin's Imitations of the Quran and The Prophet.
\end{abstract}

Keywords: Metadiscourse, marker, metalanguage, technical texts.

\section{Introduction $^{1}$}

Everything is simpler than you think and at the same time more complex than you imagine. Johann Wolfgang von Goethe (quoted in Beutler, 1962, p. 651).

Oriental discourse in Russia has been a subject of interest to scholars and the general public for quite some time. Yet, each interest group discovered and studied this subject from the perspective of its own paradigm. For example, many western historians and literary scholars saw the world through Said's Orientalism glasses; while others criticized such an approach (see Macfie, 2000, for an overview). In Russia, most historians described the emergence of oriental studies as a new development spearheaded by Catherine

1 The author is grateful to Vladimir V. Ivanov, Michael Morony, Janet Tucker, George Scanlon, Paul du Quenoy for their feedback on the earlier draft of this paper. 
II; for literary scholars it was a part of the Romantic period, while Muslim circles treated it as a spread of Islam in Russia (Schimmelpenninck, 2010).

In this paper I am taking a holistic view of the phenomenon of Oriental discourse in Russia in an attempt to understand its roots, connections and historical and literary evolution during the past three centuries. However, in doing so, I have to sacrifice depth for breadth. Both, literary and historical studies are well-developed fields in their own right; trying to combine them in one paper would be an unrealistic goal. Instead, I offer a comparative overview of two literary discourses each situated within its own context.

Literary texts sometimes have unexpected connections and sources of inspiration. However, a deeper look at these intertextual connections reveals that their appearance is not coincidental, but is a result of historical and contextual factors. Poetry occupies a special place in classical Russian literature but it is "what cannot be translated" (Yakobson, 1985). A peculiar feature of the Russian poetic tradition is its intertextuality and naturalization ${ }^{2}$ of foreign texts. Based on a comparative analysis of original Russian and early ${ }^{3}$ Arabic texts, this paper attempts to find parallels between the works of Alexander Pushkin and early Muslim texts, and to trace the interconnection between these two literatures to modern times.

I start by providing a brief review of scholarly thought on the subject, comparing and contrasting definitions, paradigms, methods and conclusions. Next, I will explore the underlying reasons for Russian interest in the East; compare the attitudes of the intellectual elite and academic circles towards this subject while tracing the development of this interest, and identifying the key personalities driving this development. I will then analyze examples of adaptation of early pre-modern Arabic texts into Russian, highlighting the causes of their success. At the end, I will reflect on the importance of a combination of favorable contextual conditions and individual action for such a development to succeed.

\section{Orient vs. Vostok}

The Orient is a delicate business (Motyl, 1970).

Given that the earth is a sphere, the directional labels North, South, East, and West are rather relative, as are their borders. The Europeans still have mixed feelings about whether to accept Turkey as a part of their continent and the

2 The term 'naturalization' here is used to refer to borrowing motives from the foreign literature to produce a localized text (c.f. Naturalized texts conference, UCLA Clark Library, June 4-5, 2004) although it may be used differently in other contexts, e.g. in English literary criticism it refers to the process of critical exegesis of a poem, that is, explaining the effects in prose.

3Although various forms of Arabic texts such as graffiti and writings on papyrus existed earlier, here I refer to the first literary texts, which appeared in $8^{\text {th }}-9^{\text {th }}$ century C.E. 
main argument of opponents is not geographical: they are "too big, too poor and too culturally different."4

The term Orient, although quite unassuming when first used, thanks to the works of Edward Said (1978) and his followers, grew to symbolize the imperial aspirations of the western powers. As a result, it acquired a negative valence almost across the board, except in Russia where Vostok - meaning 'Orient' or 'East'- escapes this kind of pejorative connotation. Although I do not deny the importance and value of Said's work, I will use the term Orient (Vostok) in its original regional meaning without the acquired imperial pedigree. $^{5}$

Various western scholars (Greenleaf, 1994; Hokanson, 1994; Layton, 1994), inspired by Said's ideas, went on a quest to find Russia's Orient which would represent the target of imperialist aspirations of the Russian empire. In what seems to be almost a confirmation bias, they interpreted the newly conquered Southern border regions of the country as Russia's Orient and the literature that engaged it as the Russian construction of self. While on the surface these arguments appear to be analytically sound, the extension of this label to the Eastern regions creates an unfortunate confounding of meanings. While Russia's South (exemplified by the Caucasus in Pushkin's work) might well be Russia's Orient in Said's terms, it has never been 'Vostok' for Russians. For them, Vostok is the Arabic and Persian world which cannot be Said's Orient simply because these regions were not a part of Russia's imperial expansion. This distinction is quite clear for Russian/Soviet scholars of the region who exclude the Caucasus and the Southern orientation when addressing the Oriental discourse in Russia (Chalisova \& Smirnov, 2000). I will follow their lead and focus on Vostok/Orient as represented by the Arab and Persian regions. Therefore, Said's framework of Orientalism remains outside of the discussion in this paper.

\section{East-West connection in Russia}

At every crossroads on the path that leads to the future, tradition has placed 10,000 men to guard the past - Maurice Maeterlinck (2015).

Depending on the point of reference, Russia can be considered East/Asia/Orient for Europe, West for Asia and North for the Caucasus. The ambiguity of Russia's East/West situation before Peter the Great 'cut the window into Europe' three centuries ago may be compared to that of modern Turkey which has been trying to add a European identity to its rich and profoundly Asian past. Before that time, Russia was indisputably a part of

4 This statement has appeared unattributed in numerous media outlets so it is difficult the trace it to the original source.

5 When used in italic, it means Said's Orient. 
Asia. "St. Petersburg... built by Italian architects, may perhaps have been considered 'Europe,' at least by the western inclined Russians themselves, but Moscow was almost certainly already 'Asia'” (Hokanson, 1994, p.2). In fact, if we look even deeper into the history of Russia, we will find how little is known about the ethnic and cultural roots of its people and their connection with the 'West.'

The first records about the 'Russian khaganate' (chaganus) in both Europe and the Arab Caliphate go back to the beginning of the $9^{\text {th }}$ century. However the sources are unclear whether the Russ belonged to Slavs (according to Hudud al-Alam (حدود العالم) , Suenos (i.e., Swedes, as per the Frankish King), Scythians (as per Byzantine patriarch Fotiy), or Avars (as per Louis II). There is still a lot of debate about the identity of the Russ (Montgomery, 2000), but it seems that the Russ were not ethnically homogeneous but were several "cruel and barbaric" nomad tribes in the steppes of Southern Russia and maybe elsewhere united together for commercial and political purposes (Golden 1995, Galkina, 2002).

The Golden Horde conquest in the $13^{\text {th }}$ century only added an additional 'Oriental' component to the peoples who were not 'Occidental' to begin with. This event known in Russia as the 'Tatar-Mongol invasion' came on the footsteps of mass Baptism in the $10^{\text {th }}$ century by the Kievan Prince Vladimir, and lasted for three centuries. Even after the territory was freed up in the early $16^{\text {th }}$ century Russia remained an almost feudal country where peasant semi-slavery was not abolished until the $19^{\text {th }}$ century.

It is only due to Peter the Great's determination to make Russia a part of Europe that we think of Russia as a European country today. By founding St. Petersburg on the former Swedish territory and making it the Russian capital and a free-trade zone and by inviting Italian architects, German engineers, Dutch shipbuilders, and French intellectuals, the Russian Tsar managed to change the perception of his country in just a few decades of the $18^{\text {th }}$ century. By the end of that century, the Russian royal family was increasingly connected by marriage with many European ones, the royal court spoke better French and German than Russian, and intellectual life rivaled that of the best European schools.

Starting from the era of Catherine II (1729) till Nicholas I (1796), the successful expansion of the Russian empire to the East and South was followed by establishing new institutions related to the religion of the newly conquered peoples - Islam: the Spiritual Assembly of Russian Muslims in Ufa, and classes and departments of Eastern languages. Numerous translations of

6 As remarked by V.V. Ivanov, there is a wealth of detailed academic studies of this region. However, since the purpose of this paper is to give a brief contextualization of the subject and not a historical study, a basic introductory text might be sufficient. 
the Quran were done also at this time. ${ }^{7}$

As a result of successful conquests, by the $19^{\text {th }}$ century the Russian empire covered almost a dozen time zones. Numerous archaeological expeditions were bringing artifacts (e.g. a copy of the one of the oldest Qurans in the world) and manuscripts to St. Petersburg, which now hosts a large collection of these in the Hermitage Museum, the Academy of Science and the Institute of Oriental Studies. ${ }^{8}$

The Asian Museum of the Academy of Science (1818) and the Institute of Oriental Studies were founded at the beginning of the $19^{\text {th }}$ century following the emergence of oriental studies in Europe, especially in France and Austria, which came about as a result of their imperial conquests in the Middle East and North Africa. The Russians did not have to go that far - since, after the Central Asian conquests of 1863-1885, all the materials could be found on their own territory; neither did their studies have a complex of superiority of the imperial type, indicating a subconscious recognition of its close historical connection with Vostok. Thus, the term 'Oriental studies' or 'Orientalearning' (востоковедение) would never have such a negative connotation as the term 'Orientalism' in the West.

\section{Oriental discourse in the Russian literary tradition}

A poet in Russia is more than a poet (Yevtushenko, 1988).

Although a few translations of oriental fables, tales and hagiographies reached Russia in the early centuries of the second millennium via the Byzantine Empire, the first Russian writings about the East were amateur travel stories. Afanasy Nikitin, a trader from Tver, described his adventures in Iran, Turkey, Arab lands and India in 1472, a quarter century before Vasco de Gama. It was followed by the travel notes of another trader Fedor Kotov in 1623 and then those of Vasily Barsky in 1778 (Ganichev, 2008).

However, the real burst of interest in the Muslim Orient began during the times of Catherine II when her expansion brought the borders of the empire into close contacts with the Eastern lands. These times coincided with the period of European Enlightenment and resulted in a bifurcation of the oriental discourse in Russia into academic studies and literary explorations. Interestingly, the academic world followed mostly the German school, while the literary circles were under the influence of the French. Voltaire, Diderot, d'Alambert were all in close contact with the Russian court. By the end of $18^{\text {th }}$ century, it was a bon ton to speak French and have a French servant or a babysitter.

\footnotetext{
7 The first time the Quran was translated into Russian under the Peter the Great in 1716. 8 I have opted to leave the literal translation of the name of this Institute (Востоковедение) instead of using the term Oriental Studies because of the negative connotation of the term 'Orientalism' and its association with the European imperialism.
} 
Quite naturally, the first translations of Oriental literature and commentaries came to Russia based on French sources (Chalisova \& Smirnov, 2000; Eberman, 1923). Therefore, these translations were not differentiated by the original language (Arabic, Persian or Turkish) but rather by genre. Several translations of the Quran were accompanied by French translators' commentaries about the life of the 'false' prophet. Another stream of translations was based on adventure and philosophical novels which started with the translation of Fables of the 1001 Nights in 1763. Although in the beginning, these were meant purely for leisure reading, by the end of the $18^{\text {th }}$ century they started to represent a form of hidden criticism of the government and the society (Kubacheva, 1962). According to perception theory (Jauss, 1982), the less shared cultural background readers have with the author, the less they are able to recognize the intended meaning. As a result, Russian writers began creating the metaphorical 'oriental' fables themselves starting the tradition of naturalization (mostly entitled as "Imitations") of oriental literature to suit the needs of their society and various groups within it. The focus of this paper is on this tradition of Russian naturalization of the oriental literature.

In order to situate the oriental discourse within the overall Russian literary tradition, a brief overview is in order. ${ }^{9}$ Scholars generally identify the $19^{\text {th }}$ century as the 'golden' age of Russian literature, ${ }^{10}$ and especially poetry. Summarizing the etymology of Russian poetry during the three centuries since its inception, Ilya Kutik (2005) breaks this period according to the main genre of each phase since "genres are the essence of the literature process." The main genre of the $18^{\text {th }}$ century represented by Gavrila Derzhavin, is the ode "Homer-like praising of the Russian victories... built on heavy metaphors, similar to awkwardly cut wooden wheels... it is a composition about the God, astral pre-destination...i.e. a pure metaphysics. The poet's 'I' is smaller than the world, he is only a man, not yet a prophet" (Kutik, 2005). The $19^{\text {th }}$ century gives rise to self-consciousness of a poet as an individual and the ode is gradually replaced by an elegy, pioneered in Russia by Vasily Zhukovskiy. An elegy is "a profoundly personal genre of crushing complaining and crying, centered on a loss that might be philosophical or personal. The elegy rolls smoothly on the rubber tires of a set of standard frameworks” (Kutik, 2005). In the $19^{\text {th }}$ century Russia saw established a tradition to view literature not as pure entertainment, but as a form of discussion about the world, the man, and the meaning of life.

\footnotetext{
9 The birth and evolution of the Russian literary tradition is not the main focus of this paper. I am providing just a few pointers to frame the discussion of the oriental discourse within this tradition.

10 This designation is used for literature at the turn of the $19^{\text {th }}-20^{\text {th }}$ centuries, beginning in 1895, the symbolist period.
} 
Poetry occupies a special place in classical Russian literature. In the introduction to the anthology of Russian poetry, Andrew Wachtel (2008) writes:

To any well-educated Russian it goes without saying that the glory of Russian literature is its poetic tradition. The works of such central figures as Pushkin, Lermontov, Tyutchev, Blok, Mandelstam, Pasternak, Tsvetaeva and Brodsky as well as those of a host of less renowned figures are treasured by the entire literate population, memorized, recited, and applied to the trials and tribulations of everyday life. This focus on the poetic tradition stands in stark contrast to the general opinion about Russian literature in Europe and the United States, where readers are far more apt to recognize prose writers like Gogol, Turgenev, Tolstoy, Dostoevsky, Chekhov, Bulgakov and Solzhenitsyn than any of the poets mentioned above. To some extent this divergence of opinion is inevitable. "Poetry," quipped Roman Jakobson, "is what cannot be translated." While this is undoubtedly an exaggeration, poetry, like certain wines, frequently does not export well.

If we cannot translate the poetry, what do we do with it? There are basically two choices (borrowing the terms from the scholars of hadiths

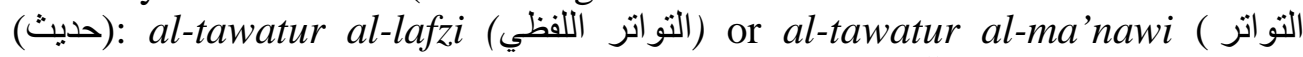
- a strict to the nail literal translation (Übersetzung, which is obviously not poetry, or a poetic retelling of the main idea (Nachdichtung). In this case, the translation would be similar to a cousin of the original. However, in reality there are many more cousins and distant relatives than the close ones, which in literature are referred to as naturalized texts (Naturalized Texts, 2004). Naturalization is different from translation in its underlying purpose: the translation is striving to remain as close to the original as possible, while naturalization makes a conscious effort to adapt the text to a new cultural, moral or political purpose. For prose, choosing between translation and naturalization is a matter of choice; however, in the case of poetry it might be a natural, if not singular, option, especially in the light of the poststructuralist idea of the ambiguity of the textual meaning. Indeed, if we attempt to do the al-tawatur al-ma'nawi, whose meaning are we trying to convey: the author's or our perception thereof, or maybe even an intentional statement of our own meaning?

Naturalization refers to the adaptation of the whole plot of the text. However, a more frequent phenomenon in the literature is intertextuality, whereby certain topics 'travel' across time and space. The term intertextuality was introduced by the Soviet philosopher of language Mikhail Bakhtin in reference to "the ready-made quality of linguistic that a writer finds available in earlier texts" (Bal \& Bryson, 1991, p. 206). The concept of intertextuality implies first and foremost that the literary forms borrowed from the past come with a meaning. Not that the later writer necessarily endorses that meaning; 
but "will inevitably have to deal with it: reject or reverse it, ironize it, or simply, often unaware, insert it in the new text” (Bal \& Bryson, 1991, p. 207). If in other literatures intertextuality is just one of the components, in Russian it is its raison d'etre (Wachtel, 2008):

Most important is that it is a tradition; that is to say, writers and readers of Russian poetry do not create or consume individual poems so much as they place those works in a living poetic fabric through a complex web of intertextual citation and reference. Regarding the Anglo-American "tradition," Harold Bloom has famously spoken of the crushing weight of the "anxiety of influence;" in the Russian tradition, it would be better to speak, as Michael Wachtel has done, of an "anxiety to be influenced," which is not so much a burden as a challenge. For a writer, the challenge is not to avoid the shadow of his or her predecessors, but rather to bring each new work into what Ilya Kutik calls "the citational epic of Russian poetry," simultaneously echoing and modifying the tradition. For the reader the challenge is to recognize the links in the chain, to see the ways in which each new poem relates to the tradition, and to see how the tradition has itself been modified by the inclusion of newer works. In this living fabric each successful new poem exerts an influence on its predecessors as much as it is influenced by them.

The original source of the intertextual elaborations is mostly lost in time, but sometimes is known. Michel Foucault (1984) provides us with a useful framework that will help to address this question. He points out the peculiar role of the author who, being identified by the corpus of his work, serves in turn as an identifier of newly found unattributed texts. Additionally, some authors are also the founders of 'discursivity,' and produce not only their own works but also the possibility and the rules of formation of other texts, thus establishing an endless possibility of discourse (Foucault, 1984). Subsequent interaction of several discourses could potentially have produced what Kilito calls "a polyandrous ode" that "resembles texts whose authorship is uncertain but whose subject and style call to mind the names of several authors” (Kilito, 2001, p. 33).

The style of oriental translations and imitations in the $18^{\text {th }}$ century had an orientation of al-tawattur al-ma'nawi - delivering the meaning of the oriental works in the form of the Russian literary tradition of that time. The authorship was sometimes omitted, increasing the feeling of a 'universal story.' The 'oriental accent' was achieved by adding excessive and flowery descriptions, and anchoring with 'oriental' words (harem, sultan, vizier, Scheherazade etc.) and locations. Curiously, archaic Russian language known from the earlier translations of the Bible was also used to 'orientalize' literary texts.

The situation started to change in the early $19^{\text {th }}$ century when the first direct translations from the originals and the names of the original authors 
(Saadi, Hafiz, etc.) started to appear within the walls of the new 'Asian' academic institutions. The difference between original languages results in stylistic differentiation between Arabic - a strong and clear language of a Bedouin; Persian - the sweet language of love similar to a nightingale's song; and Turkish - the strong and threatening language of a soldier (Chalisova \& Smirnov, 2000). As understanding of the original languages and style grows, the 'oriental style' of translations and imitations was being modified by adding specifically semitic linguistic forms ("And it was that...And it became that... There is no but...") and metaphors ("the pearls of tears").

While the direct translations increased understanding of oriental literary works, they also lead to a realization that oriental poetry heavily wrapped in adjectives and metaphors can only be truthfully translated as prose with copious footnotes. "Persian pearls became mortar bricks when translated into Russian” (Chalisova \& Smirnov, 2000, p.285). Moreover, as Natalia Chalisova and Andrei Smirnov (2000) demonstrated, there was a fundamental difference in how oriental and western authors built their texts. The western style (including Russian) develops a 'horizontal' narrative where events progress towards culmination. The reader experiences aesthetic pleasure from guessing and learning 'what happens next.' In the oriental style, the development of the narrative is 'vertical': the reader is discovering the linkages between the chains of meanings in metaphors without any obvious progress of the plot (Chalisova \& Smirnov, 2000). In fact, oriental narratives are often timeless where "nothing happens" - in terms of western understanding. What Monica Greenleaf (1994) sees as 'fragmentariness' in Pushkin's style and identifies as a reflection of the western modernist style, might well be an effort to stylistically imitate oriental literature.

This profound understanding of the fundamentals of the oriental style was not known in Russia at the time. Thus, the translators and the readers perceived original 'Asiatic style' as heavy and indigestible. Pushkin complains to Zhukovskiy and Vyazemskiy about the "ugliness of the style of Hafiz, Saadi and Muhammed." ${ }^{11}$ As a result, more and more poets opted for naturalizations and imitations abandoning the idea of staying close to the text of the original. Wilhelm von Humboldt calls the art of poetic translation "an ability to keep foreignness but get rid of the strangeness" (quoted in Chalisova \& Smirnov, 2000, p. 262). This trend enabled Russian authors to develop their own voice, being indebted to the Orient only for their metaphors and small stylistic nuances.

The poetry always goes back to the personalities of its authors,

11 "...знаешь, почему я не люблю Мура? -- потому что он чересчур уже восточен. Он подражает ребячески и уродливо -- ребячеству и уродливости Саади, Гафиза и Магомета. Европеец, и в упоении восточной роскоши, должен сохранить вкус и взор европейца" A letter to P.A. Vyazemsky, X, 125, March/April 1825, Pushkin (1999). 
especially the founders of discourses, and the historical-cultural context they were working in. Although many Russian poets imitated an oriental style, this paper focuses on the indisputably greatest Russian poet of all times. ${ }^{12}$

\section{Alexander Pushkin (1799-1837)}

Pushkin's poetry was introducing the Russian language to the children in its perfect splendor: the language, which they, probably, will never hear and will never speak but it will remain with them as an eternal treasure - Anna Akhmatova (1965).

According to Victor Zhirmunskiy, Alexander Pushkin was "the founder of Russian national literature” (Zhirmunskiy, 1937, p. 66). Each line written by him, and each day of his life have been diligently studied by scholars. The scholars of Pushkin's life and work, called 'Pushkinists' in Russia, have explored myriads of subjects related to the great poet. Yet, some aspects of his life still remain underexplored.

Similarly to the subjects of Russian historiography and literary tradition, Pushkin studies are too vast to be succinctly summarized within the limits of one paper. Therefore, I provide just a brief introduction to the life of the great poet and then focus on the central subject of this paper: oriental discourse in Pushkin's works.

Alexander Pushkin was born into a family of poets in the last year of the $18^{\text {th }}$ century, and thus symbolically became the founding father of the golden age of Russian poetry. Yet, Pushkin did not have a pure Russian ancestry, as his great-grandfather, Abram Petrovich Gannibal, had been an East-African captive at the service of Peter the Great (but later became his godson and a general). In the poem My Genealogy, Pushkin comments:

И сходно купленный арап

Возрос усерден, неподкупен, Царю наперсник, а не раб.

A conveniently bought blackamoor

Grew up hard working and honest

Tsar's confidant and not his slave.

Although Pushkin had an awareness of his African origin, he considered himself a part of Russian bourgeoisie13 and even "cold-blooded, rational European” (Nepomnyashchy, Svobodny, \& Trigos, 2006). Later,

12 Although the ranks of greatness of Russian writers may be disputed, everyone agrees on the greatest Russian poet, Pushkin. Nabokov even thinks that he was the greatest poet this world was blessed with since the time of Shakespeare (Boyd, 2011, p. 203). See also Pushkin, the Spiritual Father of Russian Poetry (2009).

13 In fact, the poem My Genealogy was repeatedly proclaiming just that. 
being exiled from the capital cities in his early 20s because of the Emperor's dissatisfaction with his conduct and poetry, Pushkin's travels to Southern Russia, the Caucasus, and Turkey might have helped him to discover an exotic inner self that is in harmony with his multiracial looks.14

This period is rich in poetry inspired by the southern and oriental spirit: The Captive of the Caucasus («Кавказский пленник»), Southern Poems («Южные поэмыл»), The Fountain of Bakhchisarai («Бахчисарайский фонтан»), and The Talisman («Талисман»). ${ }^{15}$ "The oriental style was a model for me to the extent possible for us, cold-blooded, rational Europeans,"wrote Pushkin. ${ }^{16}$ The Southern poems related to the Caucasus were thoroughly analyzed by western and Russian scholars and are not a subject of this paper. The two most interesting and relevant for the subject of Oriental discourse are the little known in Russia: The Imitations of the Quran («Подражания Корану», 1824) ${ }^{17}$ and the controversial The Prophet («Пророк», 1826).

The history of The Imitations is relatively well documented. Pushkin started working on this poem as soon as he came back from his southern exile in October 1824. At that time, all the reading public in St. Petersburg was reading the newly translated historic-philological studies of Aimable Louis Michel Brechillet Jourdain (about Persian literature) and Mihał Bobrowski (about Arabic literature) (Chalisova \& Smirnov, 2000). Already in November Pushkin writes to his brother Lev: "I am working to honor the Quran and have written something new..."18 Originally, Pushkin did not seem to conceive it as a poetic 'cycle.' Based on the chronological studies of Pushkin's notebooks, scholars came to a conclusion that nine parts of The Imitations were first written as individual poems and only later organized into a cycle sometime in April-May 1825.

The Imitations is an unambiguous naturalization with a direct reference, whose title probably indicates Pushkin's awareness of the

\footnotetext{
14 Janet Tucker remarks that "in a way, all non-Russian cultures and settings may have been "exotic" to Pushkin, who managed to "travel" through his imagination and his work in a way denied to him in actuality. These settings may all be linked with his notion of freedom. In the South, he thought he'd get to go to non-Russian territory, only to learn that that territory had just been conquered by the Russians. He bemoaned the fate that had caused him to be born in Russia instead of France. He's so miraculously complex, and he always "walked by himself," to at least an extent, while at the same time identifying with ancient Russian nobility and with the poet/intellectuals of his, and perhaps all, generations.” (Personal communication, 2004). 15 All quotes from Pushkin in Russian are given from Pushkin (1999).

16 «Слог восточный был для меня образцом, сколько возможно нам, благоразумным, холодным европейцам» A letter to P.A. Vyazemsky, X, 122, March/April 1825 in Pushkin (1999).

17 English translation of The Imitations is mine. Arabic text of the Quran from The Quran (n.d.).English translation is from Ali (1999).

18 Letter to L.S. Pushkin, XIII, 119. 1-10 November 1824. Pushkin (1999).
} 
'untranslatability' of the scripture and creates an association with a new trend in the Russian literary circles to write 'imitations. ${ }^{19}$ In the footnote, Pushkin remarks: "Here I am offering a few free imitations. In the original, Allah speaks from his own name and refers to Muhammad in second or third person." ${ }^{20}$ Pushkin chose to speak with Allah's, Muhammad's and his own voice and takes the full ownership of his work: "My Quran went from person to person - but the believers are still waiting for it”. ${ }^{21}$

What was the primary source used by Pushkin? Georgy Dimov (2008) suggests that Pushkin may have initially read the translation of the Quran from French while taking the course on the history of religions in the lyceum. At that time, Pushkin was reading 'complicated texts' in French. Even later, he asks his brother to send him a Bible "in French, absolutely in French." 22 The Quran in the lyceum had an introduction by Humphrey Prideaux, which depicted Islam in negative terms. Thus, Pushkin's skeptical footnote “The unbelievers think that the Quran is a compilation of new lies and old fables. The unbelievers are of course right in this judgment" ${ }^{23}$ might be a result of these early ideas inspired by Prideaux.

Earlier, Ksenia Kashtaleva (1928) suggested that for his Imitations Pushkin would have used Mikhail Verevkin's translation of the Quran from French published in 1790. Mikhail Verevkin was born into a family of Russian nobles and had uncanny linguistic abilities. After graduating from Moscow University he was appointed as a director of gymnasium in Kazan - the center of Tatar population. There, he developed a passion for oriental culture and literature and translated several books, including the Quran of André Du Ryé. The introduction written by Verevkin, represented the holy book of the Muslims in a positive light. He highlighted the importance of the moral and ethical norms contained therein, the beauty of the language and style and the necessity of understanding of the Arabian context in order to understand the text (Dimov, 2008). Certainly, this introduction should have had a positive influence on Pushkin's attitude towards this book, which he later calls "delightful."

Pushkin's verses never aimed at a poetic rendering of the entire holy book. For example, Quran's first surah al-Fatiha (الفاتحة) is omitted from his

19 In the early edition The Imitations of the Quran follow another poem, The Imitations of the Ancient.

20 “Здесь предлагается несколько вольных подражаний. В подлиннике Алла везде говорит от своего имени, а о Магомете упоминается только во втором или третьем лице.” Pushkin (1999). pp 213.

21 «Мой Коран пошел по рукам - и доныне правоверные ожидают его» Letter to P.A. Vyazemsky, 29 November, 1824. Pushkin (1999).

22 “Библию! Библию! И французскую непременно” Письмо к брату. Pushkin (1999).

23 «Нечестивые...думают, что Коран есть собрание новой лжи и старых басен. Мнение сих нечестивых, конечно, справедливо.» Pushkin (1999). V.2, pp. 213 
poem. Sergei A. Fomichev (1978) suggests that the poem was designed to cover the most important parts of Muhammad's life: the first and third verses refer to the escape from Mecca to Medina in 622; the second - to his marriage with Zeinab in 627; the sixth - about his return to Mecca in 630; the seventh - to communication with God from a cave in the desert.

The Imitations are beautiful and light, as are all Pushkin's texts, and can be easily cross-indexed to the source. Gadji Ziraddin Tagiev showed that The Imitations used themes from 19 surahs and 142 ayahs (Sugarenko, 2003). My goal in this paper is to identify this connection not with Russian or French translations of the Quran but with the Arabic original. Although Pushkin did not know Arabic, an understanding of path from the primordial source to The Imitations is an important part of studying naturalization.

In the first part of the poem we read about the revelation of the Quran and the description of an all-merciful all-loving God who loves Muhammad and all the believers. Similarly to the Quran, where Allah swears by the horseshoes, the fruit of the fig tree, the freedom of Mecca, the sin and the goodwill, by the angels and the men, God swears by all possible things.

\section{I}

I swear by the even and by the odd, I swear by the sword and by the righteous fight, I swear by the morning star, I swear by the evening prayer -

No, I haven't abandoned you! Whom have I introduced, lovingly, Into the shadow of consolation And hidden from the persecution? Was it not I who gave you water In the time of the desert thirst? Was it not I who gave you a present Of a tongue that can rule the minds?

Have courage! Despise the lies And follow the path of truth Love orphans and teach My Quran To all the trembling beings.

The possessive "my" with reference to the Quran emphasizes the divine nature of the scripture, while the encouragement to "love the orphans" was probably inspired by the surah Al Ma’un 3-107:1 (الماعون): 


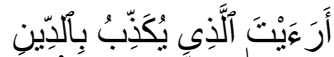

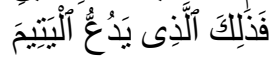

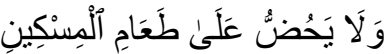

Seest thou one who denies the Judgment?

Then such is the (man) who repulses the orphans (with harshness).

And encourages not the feeding of the indigent.”

The second part of The Imitation is devoted to the wives of Muhammad:

\section{II}

$\mathrm{O}$, the pure wives of the Prophet

You are different from all other wives:

You are afraid to catch even a shadow of a sin

While resting under the shadow of silence.

Live modestly! It is appropriate for you

To have a veil of an unmarried virgin.

Keep your loyal hearts

For the lawful and private pleasures -

Not let the unbelievers' gaze

Touch your face.

And you, Muhammad's guests,

When coming for his evening prayer,

Do not confuse My Prophet

With your mundane concerns.

While flying in the realm of good thoughts

He does not like superfluous,

Vulgar and verbose talks.

Honor his feast with your obedience

And with the virgin submission

Of his young concubines.

The Quran says in the Surah Al Ahzab 33:32 (الأحز اب):

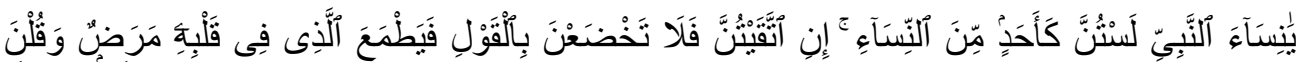

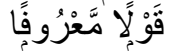


O Consorts of the Prophet! Ye are not like any of the (other) women: if ye do fear (Allah), be not too complaisant of speech, lest one in whose heart is a disease should be moved with desire: but speak ye a speech (that is) just"

The third part of The Imitation is probably based on the surahs Al-Hajj (الحج)) and Al-Baqara (البقرة). It starts with the appearance of a blind man:

\section{III}

The Prophet frowned in embarrassment

When he heard the blind approaching:

He is running, but his fault does not dare

To show his astonishment.

The text of the divine scripture is given

To you, O Prophet, not for the arrogant.

Announce the Quran calmly

Without forcing the unbelievers.

What the man is so proud of?

That he was born naked?

That he has a short life to breath?

That he will die weak as he was born weak?

That the God will make him die -

As He made him be born - at His will?

That the God safe keeps his days

In good and the bad times?

That the God gave him the fruits:

And the bread, and dates and olives?

That He blessed his works,

And his settlement, and his farm fields?

But the Angel will blow his horn twice, The divine thunder will descend on the Earth And the brother will run away from his brother And the son will pull away from his mother.

And all will flow in front of God, Disfigured by the fear.

And the unbelievers will fall 
Covered by the fire and ashes.

This can be compared with several ayahs, for example the following (22:2):

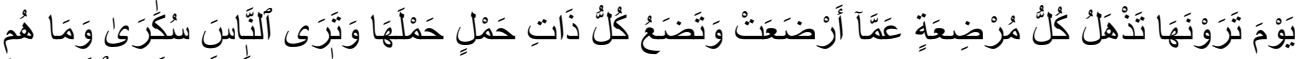

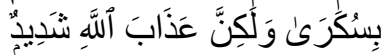

The Day ye shall see it, every mother giving suck shall forget her suckling babe and every pregnant female shall drop her load (unformed), thou shalt see mankind as in a drunken riot, yet not drunk but dreadful will be the wrath of Allah.

The fourth part corresponds to the ayah where Abraham disputes with the skeptic about the power of Allah (2:258):

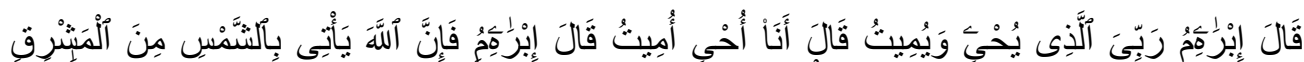

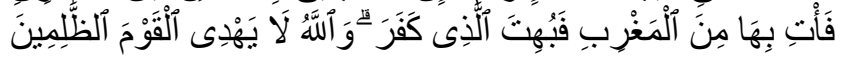

Abraham said: "My Lord is He who giveth life and death." He said: "I give life and death." Said Abraham: That it is Allah that causeth the sun to rise from the East: do thou then cause him to rise from the West?

IV

O my God! With you the Old,

Powerful one decided to wrestle,

Full of crazy arrogance.

But you, my Lord, tamed him.

You said: I give life to this world,

I punish the earth with death-

My hand is over everything!

He said: And I too, give life

And give death as punishment -

I am equal to you, God.

But the word of your anger

Silenced the sinful:

I rise the Sun from the East:

Try raising it from the West!

The fifth part is dedicated to the Creator and his power: 
The Earth is fixed, - the heavens

Is supported by you, the Creator.

Don't let them fall on the land and water

And smash us underneath!

You lighted up the sun in the Universe

To shine for the heaven and the earth

It shines as linen soaked in oil

In the crystal of a lamp.

Pray to the Creator: He is All-Powerful:

He rules the wind, in a hot day

He sends clouds on the sky,

Gives the tree shadow to the earth.

He is merciful: for Muhammad

He opened the shining Quran.

Let us too flow towards the light

Let the fog fall from our eyes.

Here the epithet "shining" is a parallel to other epithets for the Quran such as "noble", "glorious," etc. The word "flow" repeats in this part in the similar meaning as in the second part and probably alludes to the believers "flowing into the umma" (الأمة ). The comparison with "light" can be linked with one of the name of Allah Al-Noor ( النور ) and with the Surah of the same name (24:35):

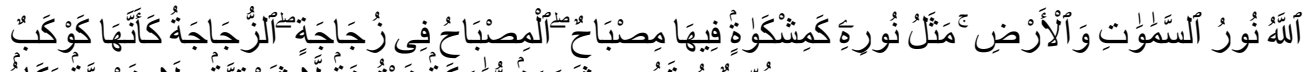

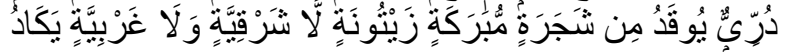

Allah is the light of the heavens and the earth. The parable of His light is as if there were a niche and within it a lamp: the lamp enclosed in glass; the glass as it were a brilliant star.

Also, in the Surah Ibrahim (ابر اهيم) we read (14:1):

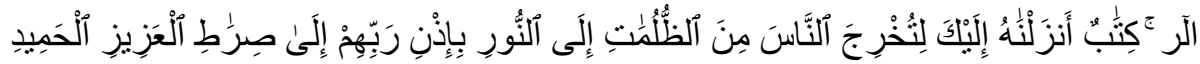

A book which we have revealed unto thee, in order that thou mightest lead mankind out of the depths of darkness into light.

However, the allegory of light-darkness is an overused binary opposition that 
is standard in almost all the religions, thus it should not necessarily be taken as a unique indicator of intertextuality.

The sixth part of the poem is devoted to the martyrs who died in the battle with the non-believers and idol worshippers and whom Paradise awaits:

\section{VI}

This was not an accident that I saw you in my dream

Going into battle with shaved heads,

With blooded swords,

In the mote, on the tower, on the wall.

Listen up the joyful call,

$\mathrm{O}$, peoples of the flaming deserts!

Take home young female slaves,

Share the booty!

You won: praise be on you,

Let the weak in soul be ridiculed:

They didn't go to fight

Not believing the wonder-dreams.

Now, seduced by the riches

They regret and say:

Take us with you.

But you say: we won't!

Praise be on the martyrs,

For they entered the Eden,

And sunken in the pleasures

Not poisoned by anything.

The seventh part, which begins with a call "Arise!” can be compared with

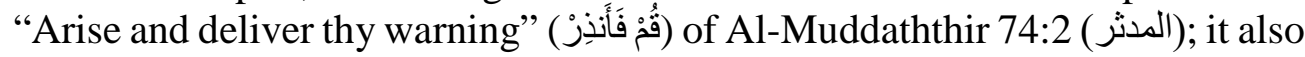
may naturalize Surah Al-Imran (العمران):

\section{VII}

Arise, o fearful! 
In your cave

The divine lamp

Is lit till dawn.

With a heartfelt prayer

O Prophet, satisfy

Your sad thoughts

And controversial dreams!

Pray submissively

Till dawn

Read the divine book

Till dawn.

The epithet "divine" can be viewed as the rebuke to those who proclaimed the man-made origin of the Quran. The words "in your cave" obviously refer to Hira cave where Muhammad was praying when Gabriel brought him the Book during the "Night of Power" (القدر). Pushkin himself had an affinity with caves that is a repeated theme in his works: "my student cell in the Lyceum," "the small grotto" in Gurzuf where he was in exile, "the big gray grotto" in Kamenka, "the inner cell of my heart." It is not surprising that The Imitation of the Quran descended on the poet in his "cave with a divine lamp" in Mikhailovskoye:

В пещере тайной, в день гоненья,

Читал я сладостный Коран.

Внезапно ангел утешенья,

Влетев, принес мне талисман.

Его таинственная сила

Слова святые начертила,

На нем безвестная рука.

In a secret cave, on a day of exile

I was reading the delightful Quran.

Suddenly, the Angel of consolation

Flew in and brought me a talisman.

Its mysterious power...

The divine words

Written by an unknown hand...

The eighth part of the poem is a prayer for the "orphans" mentioned in the first part - that resonates with several surahs, e.g. with Al Ma'un. Muhammad, as Moses, was an orphan himself, so this attitude towards those can be understood as an act of self-gratification. Zakat ( زكاة) and donations are not a favor, but a duty which is related to the perceived right of the poor on the 
wealth of the rich since all the wealth is the property of God (4:2):

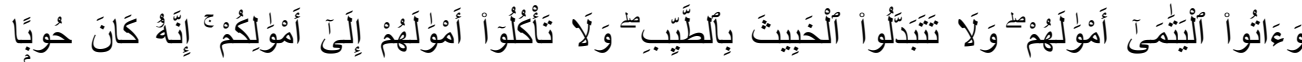
كَبيرً

To orphans restore their property...not substitute your worthless things for (their) good ones; and devour not their substance (by mixing it up) with your own. For this is indeed a great sin.

\section{VIII}

When trading your conscious with the pale poor folk

Don't disperse your gifts with your well-measured hand:

Only the full generosity is benevolent for the heavens.

At the Day of the Judgment, as a fertile field

$\mathrm{O}$, the good seeder,

It will give back to you more and above your efforts!

But if you, being greedy of your earthy labor

When giving the poor a poor charity

Close tight your envying hand -

Be aware: all your gifts will be like dust,

Which will be washed away from the stone by a strong rain -

Everything, will disappear for the God will reject your donation.

The last part of the poem is a reminiscence of the second surah where he talks about the weakness of a traveler who was upset with God, and about the mercifulness of God towards him:

\section{IX}

And the tired traveler was complaining about God:

He was thirsty and was yearning for shade.

He had been wandering in the desert for three days and three nights

And his eyes, tired from the heat and the dust,

Were hopelessly wandering around in anguish...

Suddenly, he sees a well under the palm-tree.

So he ran towards the desert palm tree

And greedily cooled with water

His burning tongue and eyes,

And lay down and fell asleep next to his loyal she-donkey;

And as many years flowed over him 
As the Lord of the Heavens and the Earth wished.

Then came the time to wake up.

He gets up and hears an unknown voice:

"How long have you been sleeping in the desert?"

He replied: "The sun was high already

Yesterday morning when I fell asleep -

I must have been sleeping from morning to morning."

But the voice said: "O, traveler you slept longer.

Look at yourself: you went to sleep young and woke up an old man.

The palm tree is gone, and the cold well is

All dried up in the waterless desert,

Covered by the sands of the steppes.

And here are the white bones of your she-donkey."

And the instantaneous old man was full of despair,

He put his head down, all in tears.

And then the miracle took place:

That what went away resurrected in a new beauty,

Again, the palm-tree has its green head

Again, the well is full of coolness and darkness.

And ancient bones of the donkey rose up

Dressed up in body, and making sounds.

And the traveler feels power and joy,

The resurrected youth is playing in his blood.

His chest is filled with excitement,

And, blessing God, he continues his road...

Similar to this traveler, Pushkin resumed his path with the Quran that continues to appear in other poems here and there. Here, he is echoing surah The Prophets 21:5 (الأنبياء):

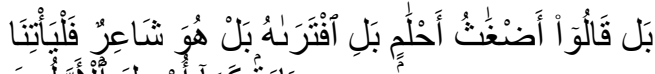

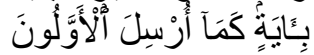

Nay, - they say -(these are) medleys of dreams! - Nay, he forged it! - Nay, he is (but) a poet!

when rebuking those who were saying that the Quran was a poetry composed by Muhammad:

Они твердили, пусть виденья

Толкует хитрый Магомет, Они ума его (творения), 
Его ль нам слушать - он поэт!

They kept saying:

Let this sly Muhammad explain his dreams.

They are the fruits of his brain.

Why should we listen to him: he is nothing but a poet!

What was the reason for Pushkin writing The Imitations and what was poem's purpose? Unfortunately, the poet himself did not give us an answer to this question. While many saw this as a sign of the poet's affinity and even conversion to Islam, Lubov Kraval (1997) suggests that one of the main reasons might have been a secret and mutual love between Pushkin and a Tatar woman Anna Girey, the god-daughter of the general Nikolai N. Raevsky. Circumstantially, Pushkin started writing it after moving from his family house in Mihailovskoe to Trigorskoe ("from Madina to Mekka") after a fight with his father who allegedly accused Pushkin of teaching atheism to his brother and sister.

Pushkin's religiosity has been a subject of many debates. In spite of poet's 'Arap' roots, dark looks and oriental poetry, his supposed secret conversion to Islam seems highly doubtful. There is a difference between "Arab" and "Arap" in Russian. As Pushkin writes to his friend Piotr Vyazemsky, "Arab is ... a native of Arabia; Arap [blackamoor] ... is what Negroes and mulattoes are usually called." So Pushkin didn't have a basis of affinity with Muslim Arabs. Calling Muhammad "sly" and agreeing with "unbelievers" that the Quran is "a collection of new lies and old fables" seem to exclude such a possibility. Pushkin might have even resented a possible personal association with Vostok/Islam as indicated by the following footnote "In order that you, my freedom loving friends, would not believe this 'Asiatness' in me, let's make fun of it." This clearly indicates that Pushkin did not want his oriental poems to be viewed as a statement of allegiance to Islam or even Asia in general. Others tried to claim a profound Orthodox Christian religiosity for the poet (Frank, 1990). Although Pushkin wrote several poems about Jesus and the Christian god ("and I will say: Jesus has resurrected!"), his adherence to Christianity seems to be only nominal, at least in the beginning of his creative years. Based on such facts as criticizing religion and affinity with secular Decembrists, the most logical conclusion seems to be Pushkin's secularism. Then, why write all these pseudo-religious poems?

In my opinion, the most plausible explanation is Pushkin's universality, or cosmopolitanism. Nikolai Gogol and Fedor Dostoyevsky both noted Pushkin's uncanny ability to reincarnate into an alien nationality and truthfully represent it in his poems (Hokanson, 1994). Jesus and Muhammad 
are nothing but cherished literary characters, as a reference of one of his friends seems to indicate. When Kondratiy Ryleev begs Pushkin not to imitate Byron but to become the Russian Byron, he resorts to such words: "please, for the sake of god, for the sake of Jesus, for the sake of your beloved Muhammad...” All Pushkin's characters lumped together become his by the virtue of introducing them to the Russians through his enchanting poetry.

The Islamic themes and ideas of the Quran do not leave Pushkin. In the early versions of Evgeny Onegin (stanza 3), we can read:

В Коране много мыслей здравых,

Вот, например: «Пред каждым сном

Молись; беги путей лукавых,

Чти Бога и не спорь с глупцом.

In the Quran, there are a lot of healthy thoughts:

For example: "Pray before going to sleep,

Stay away from doubtful paths,

Respect God and don’t argue with a fool.”

Unfortunately, the greatest Russian poet did not have the willpower to follow the last advice and was always in the middle of fights and controversies, both political and personal. Killed in a duel at the age of thirty seven, he has left us many mysteries, one of which is one of his top ten best known poems - The Prophet (Translated by W.S. McCallum).

Духовной жаждою томим, В пустыне мрачной я влачился, И шестикрылый серафим На перепутье мне явился; Перстами легкими как сон Моих зениц коснулся он: Отверзлись вещие зеницы, Как у испуганной орлицы. Моих ушей коснулся он, И их наполнил шум и звон: И внял я неба содроганье, И горний ангелов полет, И гад морских подводный ход, И дольней лозы прозябанье. И он к устам моим приник, И вырвал грешный мой язык, И празднословный и лукавый, 
И жало мудрыя змеи

В уста замершие мои

Вложил десницею кровавой.

И он мне грудь рассек мечом,

И сердце трепетное вынул,

И угль, пылающий огнем,

Во грудь отверстую водвинул.

Как труп в пустыне я лежал,

И бога глас ко мне воззвал:

"Восстань, пророк, и виждь, и внемли,

Исполнись волею моей

И, обходя моря и земли,

Глаголом жги сердца людей.

Exhausted by spiritual thirst,

Through a bleak desert I shambled,

And a six-winged seraphim

At the cross-roads before me appeared;

With fingers as light as a dream

He touched my pupils:

Opening prophetic eyes,

Sharp as a frightened eagle's.

He reached to touch my ears,

Filling them with noise and ringing:

The heavens aquiver I could hear,

And on high a flight of angel soaring,

The serpents shifting in the sea,

And vines creeping in the vale.

He stooped down to my mouth,

And my sinful tongue, idle and crafty,

With his right hand bloody tore out,

Placing into the orifice benumbed,

A wise dragon's forked tongue.

With a sword he clove my breast,

And my trembling heart plucked out,

Its substitute, a red-hot coal,

He thrust into my gaping chest.

Corpse-like in the desert I lay sprawled, And God's voice to me did call, "Arise O prophet, see and hear, So you may fulfill my will, And travel by land and the sea, 
Setting hearts ablaze with your word.

One can easily see that this powerful poem is full of intertextuality, which this time is quite difficult to trace to one source. The traditional Russian reading was to refer it back to the Bible's prophet Isaiah who says in chapter six: "One of six-winged seraphim came to me with a red-hot coal... and touched with it my mouth, and said: your sins have been cleared," then he volunteers to go and "spread the word." Although a few details are strikingly similar (the six-winged seraphim and the red-hot coal), the scenario is not: seraphim appears to Pushkin's Prophet "at the cross-road," tears out the tongue, and substitutes the heart with a coal, while Isaiah meets him by the God's throne and the coal is used for a less invasive operation with the mouth. A quick look at other sources indicates that many prophets, including Muhammad, had some kind of torturous initiation, of various degrees of intensity, into their prophethood.

The Quranic and hadith references also have a flaw. In the Quran, Allah asks: "Haven't I enlarged you the chest and freed you up from your load" and the hadiths (حديث) tell a story of the angels cutting off the chest, washing the heart with the snow, and then placing it back. Although both operations are with the chest, they are far more merciful than Pushkin's and do not involve coal. The only direct reference that may be cited is the call to "arise" and "set hearts ablaze with the word," - which became the trademark of Islam whose primary source of religion is the scripture, unlike Christianity where the primary source is Jesus. Or maybe connection even deeper, on a zāhir/batn (باطن/ظاهر ) level, whereby the poem has a multitude of meanings, all of which are meant by the author. In a spark of genius, Pushkin creates a poem that not only exhibits the examples of multiple intertextualities, but also becomes the foundation of a discourse, however, with a third candidate (quite possibly also meant by the great trickster) for the role of the Prophet: the poet himself!

Now, the reference in the beginning of the chapter: "the poet is not yet the prophet" can be fully understood in its context. Among other things, the descendant of an African captive with European self-identity, Pushkin declares himself (quite prophetically) the Prophet of the poets and, par excellence, begins the golden age in Russian poetry. Now, the 'I' of the poet is bigger than the world: not only does he claim for himself the right to "blaze the hearts with the word" and does so quite successfully, but he also gives orders to his Muse: "O Muse, obey to me by the will of God," 24 and calls himself "Prophet's [Muhammad's] Prophet." This idea seems to appeal to his fellow poets and Lermontov continues the discourse:

24 «Веленью божию, о муза, будь послушна». Pushkin (1999). 
С тех пор как вечный судия мне дал всеведенье пророка... From the times that The Highest Judge gave me the all-knowing of the Prophet...

But unlike Pushkin Lermontov had a credibility issue:

В очах людей читаю я

Страницы злобы и порока.

...Глупец, хотел уверить нас,

Что бог гласит его устами!

in the eyes of people

I read the pages of hatred and sin...

"This fool wants to convince us

That the God speaks through his mouth!”

As time progressed, the intended batn and correlation with the religious prophets was forgotten, probably unintentionally, by the next generations and then quite intentionally forbidden by the Soviets in their effort to erase religion, 'the opiate of masses,' from the face of the world. By the end of the $20^{\text {th }}$ century, students studied and analyzed only one meaning of the Prophet - the poet himself.

Meanwhile the discourse expanded to a global scale. In 1999, UNESCO conducted a contest for the best translation of Pushkin's The Prophet into any language attracting about seventy entries mostly in English and French. The next layer of naturalization has covered the subject.

After Perestroika, people in the former Soviet Union began to discover the lost meaning of the poem as witnessed by Tashkent Theater's play The Imitation of the Quran brought to Los Angeles in 2003. Naturalization of a naturalization, the play was more like a reincarnation of the life of the Prophet, the Sira (السيرة) - staged in a modern, almost futuristic style. So perhaps Foucault and Jauss are at least partially right and we do live in a new world where the author is no longer the only one who dictates the meaning, or even meanings. Instead, each reader or viewer develops his or her own unique and fascinating understanding of a work of literature or art. Maybe author's ability to provide a source for such multi-faceted understanding is the sign of a masterpiece created by a genius.

\section{The evolution of the Oriental discourse}

The Oriental style was a model for me to the extent possible for us, coldblooded, rational Europeans - Alexander Pushkin (1999). 
When describing the culture of the Russian elite of the $18^{\text {th }}$ - beginning of $19^{\text {th }}$ centuries, Yury Lotman (2002) points out the great importance of art in everyday life. During the reign of Peter the Great everyday behavior, normally subconscious and considered natural, became something new to be learned since traditional behavior had been replaced by imperial edict by new patterns modeled on European aristocratic culture. The nobility could choose from a variety of 'styles' and eventually such new patterns became theatrical as people tried to emulate an historical figure, or a character from literature. At the end of the $18^{\text {th }}$ century, an idea of a 'plot' was added to the 'style.' People started to regard one's life as a text which is organized according to the rules of a particular plot modeled based on historians of antiquity, tragedies of classicism and sometimes the lives of the saints (p. 247). In contrast with the literature elsewhere, which was depicting the life as it unfolds, in Russia of that period, the art was providing a model to copy (Tyutchev, 1996):

Russia cannot be understood with the brain,

Or measured with a common yardstick,

She has a peculiar character -

You can only believe in Her.

So, quite paradoxically, the strict academic translations or Oriental literature never crossed the paths with poetic imitations à la français. The Russian Empire was built upon a foundation of culture, rather than being of a scientific nature familiar to other European nations. Thus, the interest towards the Orient/Vostok was brought to the Russian masses by the poets and writers who, in turn, borrowed it from the Europeans, mostly French, who were at that time in the full swing of their own Oriental discoveries as part of their imperial expansion into the Levant and North Africa. But contrary to the European imperial Orientalism, the Russians viewed Vostok just as an inspiration, a type of literary 'style' to 'try on' as a part of their creative explorations. This attitude made a quest for the origins of such style largely irrelevant.

Meanwhile, not many academic scholars considered themselves poets. They continued their studies and translation of the manuscripts available in the St. Petersburg archives, albeit in a pedantic word-by-word manner. They were discovering several Arabic-Russian technical parallels: in phonetics (several similarly sounding sounds), language structure (cases and inclinations), meter, and rhyme.

Being from the cultural elite themselves, the scholars were well aware of the oriental discourse of the poets while remaining largely ignored by them. So in addition to the technical parallels, they began to see other, more intangible ones. The glorifying genre of the Russian ode was very similar to the Jahiliah fakhr (فخر الجاهلية) and was similarly full of colorful metaphors. 
The basis of the Russian literary discourse, intertextuality, was also prominent in the early Arab works where the stories and metaphors (e.g. "the pearls of tears") were migrating from the oral pre-Islamic texts into early classical literature, as well as re-used within the body of the works of the same poet (Kilito, 1990). For example, the Al-Akhtal's (الأخطل) drinking party in Theodor Noeldeke's Delectus (1890, p. 28) only partially overlaps with the poem in the Russian manuscript translated by N. Maltseva (Filtishinskiy, 1996, p. 59), but the common parts are the most colorful ones: "the wine in my bones crawls as the ants in the sand."

تدب دبيبا في العظام كأنه دبيب نمل في نقا يتهيل

The $19^{\text {th }}$ century's golden age of Russian poetry can be compared with the early classical period of the Umayyads, which also had similar poetic genres (Filtishinskiy, 1996, p.32): elegy, lyric and satire.

\section{The love discourse}

In Arabic poetry, the elegy takes its roots from the first nasib (نسيب) sections of the pre-Islamic tripartite qasida (قصيدة) as exemplified by Imrual-Qais (أمرؤ القيس): "Stop, you two, let us weep on my past love, on her deserted camp - although I will never find its traces" (Filtishinskiy, 1996, p.32).

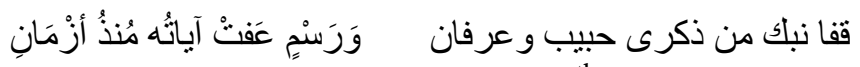

However, the real love discourse started by the $7^{\text {th }}$ century Udhri poet Qays ibn al-Mulawwah (عذري ) (قيس ابن الملولح), "the most famous of the famous lovers,” whose Diwan Majnun Layla ( ديوان مجنون ليلى ") became the Romeo and Juliet of the Islamic world (Khan, n.d.). Qays' Diwan was the source of naturalization first by the $13^{\text {th }}$ century Nizami, Amir Khosrow and then by the $15^{\text {th }}$ century Central Asian poet Alisher Navoi (1990), whose work was then translated into Russian. Comparing this translation with the original Arabic text demonstrates the striking effects of naturalization. Qays' Diwan is a descriptive, schematic qasida-like song "where nothing happens," which as Filtishinsky (1996) points out, is a feature of Jahiliah's texts, 25 while Navoi's poem is a story with a continuous plot and a philosophical humanistic conclusion about the meaning of life and happiness.

25 Filtishinsky maintains that “ancient oral lyric-epic poetry was initially developed from the magical rituals of Bedouin tribes, in which the poet played an important role: he was able to conduct magic rituals, find water sources in the desert, be the historian of the tribe, protector of the tribe's honor and a judge in inter-tribal disputes...The Bedouin poet was not trying to amaze the listeners by the originality of his thought or dareness of his creativity; he had merely tried to describe an event, a natural phenomenon or a concrete object with a maximum precision. The world was static for him as were his conditions of life," hence the synchronic nature of the qasida. However, to exhibit his talent "the poet had to make his descriptions as expressive as possible.” Filtishinskiy (1996, p. 6). 
Similarly to the Russian elegies of Mikhail Lermontov, Alexander Blok and Fedor Tyutchev - the Udhri love poetry treats suffering as an art in itself. As Michael Dols points out, "ultimately the song [of Majnun] was more important than its object" (quoted in Fathi (n.d.)). In reality the song was really about the singer. The Russian classical elegy "is not the truth about self, the author, but a set of 'molds' about self, or clichés that the author uses to describe himself in a way he wants the readers to perceive him...his goal is to provoke the readers to think about themselves using the frameworks that he offers to them"(Wachtel, 2014).

On the other hand, the Hijazi (حجازي) erotic style initiated by Umar bin Abi Rabi'ah (عمر بن أبي ربيعة) is more like Pushkin's love lyrics. The great poet, in spite of his arguably unattractive appearance had great success with women and his poetry was rarely melancholic. He should have believed that "although to have all the women in the world is not an achievable goal, we have at least to strive towards it." His poetry might, at least partially, have exaggerated the real events similarly to Umar's verses. Both have no problems to court the target, trick her into a liaison using the arms of poetic clichés ("I love you forever; nobody else was in my heart before you!" (Filtishinskiy, 1996, p. 86). - exclaims Umar) and behavioral tools ("The less we love a woman, the more we are attractive for her"26 - suggests Pushkin). As some of their targets were inevitably somebody else's property, both ended up having trouble with other men. As if it was not enough, Pushkin also engaged in another, more dangerous genre of political satire.

\section{The satiric discourse}

Satire (hija, هجاء) was one of the relatively younger discourses in the classical Arabic literature: the poetry was more a rhetorical exercise than a political tool before Islam. In the first century of the Caliphate, famous Arab poets started coming to the Umayyad capital in Damascus and cultural centers, Kufa and Basra, to glorify the power of the caliphs and his emirs through a traditional poetic competition. The famous triad of Umayyad satirists of the early $8^{\text {th }}$ century, Al-Akhtal (الأخطل), Al-Farazdak (الفرزدق) and Jarir (جرير) were exercising their poetic skills by verbally attacking each other27 and, by extension, their clans and sponsors. Because the declared audience was one of them, the satirists could bring the hija to incredible heights without running the risk of being politically incorrect. And thus, the extent of their imagination had no limits: Jarir calls Farazdak's father "a dirty pond not good enough to

26 «Чем меньше женщину мы любим, тем легче нравимся мы ей». А. С. Пушкин, Евгений Онегин, Ch. 4, Stanza 7. Pushkin (1999).

27 Mainly, Farazdak vs. Jarir. 
even bathe a donkey in" (Filtishinskiy, 1996, p. 62):

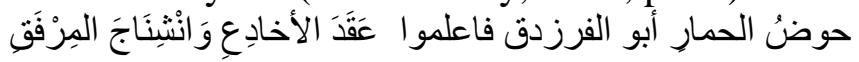

while Al-Akhtal trashes Jarir with the most famous 13-fold insult in the Arabic poetry: "when you hear the guests approaching in the desert you ask you mother to pee on the camp fire so that they couldn't find you"(p. 370).

قوم إذا استنبح الأضياف كلبهم لأمهم قالو ا:على بولي النار

Meanwhile, the real target is the poets' political and tribal sponsors, while the audience is first of all their adversaries. This tradition is very similar to $19^{\text {th }}$ century academia in Europe where the scholars attacked oriental society as an indirect way to criticize their own. However, this was not always the case in Russia where the methods were sometimes more direct and unambiguous. "Farewell, my 'unwashed' Patria," exclaims Lermontov departing in exile, "the country of slaves, the country of masters..." 28 The unsuccessful 'prophet' Lermontov announces nevertheless in his The Prophecy: "There will be a black year for Russia, when the crowns will fall from the heads of its Tsars." 29

In addition, Pushkin did not mind mixing in an erotic element into his political satire. For example, when writing to the general Mikhail Orlov on the occasion of his unsuccessful courtship of a ballerina: "Without even thinking of offending her sweetheart, Laisa has taken a microscope and said: let me see this armory with which you were trying to take my fortress. ${ }^{30}$ He did not mind addressing even the Tsar Alexander I: "You are cleaning your fat behind with a French paper, while I don't mind using the rough page with Khvostov's ode to you." 31

As an old saying goes, "the pen is mightier than the sword," especially if it is Pushkin's. He set many people's hearts ablaze with his words, but such great courage inevitably brings about great risks, thus it is no surprise that the great poet was killed in a duel at the age of thirty seven. "A black stretcher

28 «Прощай, немытая Россия, страна рабов, страна господ», 1840-1841: 403. РС. 1887, № 12. Pushkin (1999).

29 «Настанет год, России черный год, когда царей корона упадет» - «Предсказание». 1830 111. Изд. 1862, ПСС-1, т. 1. — - Печ. по автографу ПД, тетр. 6. Pushkin (1999).

30 «Не думав милого обидеть/ взяла Лаиса микроскоп/ и говорит: «Позволь увидеть,/ чем ты меня, мой милый, ё...» Томашевский Б. В. Примечания. 454. Эта эпиграмма сохранилась в списках. Орлов Михаил Федорович (1788-1842) - генерал, член «Арзамаса», позднее член Союза благоденствия. Pushkin (1999).

31 «...афедрон ты жирный свой/ подтираешь коленкором/я же грешную дыру/ не балую детской модой/ и Хвостова жесткой одой/ хоть и морщуся, да тру.» - Tbl u я (р. 110). Сатира на Александра I. Хвостов, гр. Дмитрий Иванович (1757-1835) - бездарный и плодовитый поэт, осмеивавшийся Пушкиным с лицейских времен вплоть до 1833 г. Pushkin (1999). 
bears away yesterday's sun”32 - said Osip Mandelshtam (1990). For most people, Pushkin remains The Prophet. His prophecy proclaimed for himself has been fulfilled (Pushkin, 1999):

A monument I've raised that never hands could build, The people's path to it will not be overgrown. ${ }^{33}$

\section{When the Poet meets the Scholar}

It is often said that history is a sequence of events linked by complex causal relationships. While it is true that the climatic, geographic and other natural factors play an important part in these relationships, the role of an individual in history should not be underestimated. The great poets are the founders of discourses in the cultural heritage of their societies and sources of the texts that later become subject to naturalization. As Vasiliy Bartold points out, "the main driver of the progress in a society is the interaction between different cultures" (Bartold, 1966, p. 146). I would only add that the interaction between different disciplines is a great contributor to societal progress as well.

The literary and academic circles would have probably continued their happy coexistence in Russia, where one was ignoring the other while the other was quietly learning from it, if not for the Socialist revolution of 1917. The Russian aristocracy, literary bohemians, and artistic elite fled to the West while those left behind were consolidated under the auspices of the Soviet Academy of Sciences. This is when the real cooperation commenced and carried on until today - the poets finally do real adaptations, rather than mere naturalizations based on thorough literal translations by the scholars who believe that "understanding the Arabs without Arabic is more difficult than understanding the Greeks without Greek" (Bartold, 1966, p. 252). In the words of Chalisova and Smirnov (2000): "towards the middle of the $20^{\text {th }}$ century the Russian Oriental school looked like centaurs composed of a 'body' made of mechanical literal translations and a 'head' representing a creative poet who was rendering these translations into Russian poetry”(Chalisova \& Smirnov, 2000).

At that time, the Arab poets have finally become known to the wide Russian reading public under their own names, with their works skillfully put in verses of similar meter and rhyme by professional poets based on the literal translations of the scholars. Because of this happy collaboration we can now feel the burning pain of Majnun and laugh at the sharp-witted remarks of Jarir and Farazdak, sometimes wondering how they could come up with such

32 «И вчерашнее солнце на черных носилках несут» Mandelshtam (1990).

33 «Я памятник себе воздвиг нерукотворный, к нему не зарастет народная тропа» 
precise yet sophisticated words in Russian.

\section{Conclusion}

The purpose of this paper is to clarify and reconcile various, sometimes not even overlapping, streams of research related to Oriental discourse in the Russian literary tradition. Putting together all parts of the discussion we may arrive at several conclusions.

First, although using the lens of Said's Orientalism might be useful for studying the imperial aspect of Russian historical and literary heritages, it should not be extended into all Asian/Eastern regions and themes. While casting the Caucasus and other southern territories in Said's terms may be valid, placing the Arab and Persian East under the same umbrella is not. In the Russian mind, the South is different from the East/Orient/Vostok and the latter has no negative connotations of the imperial type.

Second, the acquaintance of Russian scholarly and literary circles with Vostok followed different paths. Scholarly studies and translations ('Orientalearning') followed the German school, while literary development ('Orientafeeling') was riding on the wave of the European, mostly French enlightenment. These two strands would meet again only in the $20^{\text {th }}$ century when they were brought together by the Soviets under the auspices of the Academy of Sciences.

Third, although early literary works attempted to render precise translations of the originals (albeit via French), almost immediately Russian writers shifted to free 'imitations' (naturalizations) of the text because the apparent thickness of descriptions and fragmentariness of the original narrative made precise translations unattractive for the Russian reading public.

Fourth, Russian oriental imitations were (and should be) viewed as independent products of the Russian authors who borrowed only ideas from the original, while writing poetry in a truly Russian literary style, 'spiced up' by oriental names, locations, and metaphors. In this sense, these works were truly naturalizations rather than translations or even imitations.

Fifth, while in the beginning oriental naturalizations were produced to entertain, later they were used to teach philosophical or moral lessons and even as a rhetorical device to critique the government. In this sense, the styles of oriental naturalizations were very similar to (although not borrowed from) those of the classical Arabic poetry, especially elegy and satire.

Overall, although Russian Oriental literary discourse started and was inspired by the French Enlightenment, which had the strong imperial overtones uncovered by Said, soon after it grew in a totally independent phenomenon of naturalization of the oriental texts, appropriating their ideas and literary characters but providing them with a new, Russian soul, and meaning. As a result, Russian Vostokian naturalizations have become an 
inseparable part of the native Russian literary tradition since the $19^{\text {th }}$ century.

\section{References:}

1. Akhmatova, A. (1965). Pushkin and children. [Ахматова, А. (1965). Пушкин $u$ дети.] Retrieved from http://bookonline.com.ua/read.php?book=1723

2. Ali, A. Y. (1999). The Meaning of The Holy Quran. Beltsville: Amana Publications.

3. Bal, M. \& Bryson, N. (1991). Semiotics and Art History. The Art Bulletin, 73:2, 174-208.

4. Bartold, V. V. (1966). Works on the History of Islam and the Arab Khaliphate. Moscow: Oriental Literature. [Бартольд, В. В. (1966). Работы по Истории Ислама и Арабского Халифата. Москва: Восточная Литература.]

5. Beutler E. (Ed.). (1962). Johann Wolfgang Goethe: Collected Works, Letters and Conversations. Vol. 9. Zurich, Switzerland: ArtemisVerlag.

6. Boyd, B. (2011). Stalking Nabokov: Selected Essays. New York, NY: Columbia University Press.

7. Chalisova, N. I. \& Smirnov, A. V. (2000). Imitations of the Oriental Poets: an Encounter of the Russian Poetry and the Arab-Persian Poetics. Comparative Philosophy. Moscow: Oriental Literature, 245344. [Чалисова, Н. И. \& Смирнов, А. В. (2000). Подражания восточным стихотворцам: встреча русской поэзии и арабоперсидской поэтики. Сравнительная философия, Москва, Вост. лит-ра, 245-344.

8. Dimov, G. (n.d.). Mekka in the Poet’s Destiny. [Димов, Г. «Мекка» 8 судьбе поэта.] Retrieved from http://www.ruscenter.ru/610.html.

9. Eberman, V. A. (1923). The Arabs and the Persians in the Russian Poetry. Vostok. V.3. Moscow-Leningrad. [Эберман, В. А. (1923). Арабы и персы в русской поэзии. Восток, кн. 3. М.-Л.]

10. Fathi, A. (n.d.) Umar b. Abi Rabi'ah (working paper).

11. Filtishinskiy, I. M. (1996). A Pearl Necklace. Moscow: Oriental Literature. [Фильштинский, И. М. (1996). Жемчужное Ожерелье. Москва: Восточная Литература.]

12. Fomichevm S. A. (1981). The Imitations of the Quran: Genesis, Architectonics, and Composition. Vremennik of Pushkin's Commission, USSR Academy of Science. Leningrad, Nauka, 22-45. [Фомичев, С. А. (1981). Подражания Корану: Генезис, архитектоника и композиция цикла. Временник Пушкинской комиссии, АН СССР. Лениград: Наука. 22-45.]

13. Foucault, M. (1984). What is an Author. In P. Rabinow (Ed.). The 
Foucault Reader (pp. 101-120). New York, NY: Pantheon Books.

14. Frank, S. L. (1990). Pushkin's Religiosity. Pushkin in Russian Philosophical Critical Studies. Moscow, 380-96. [Франк, С. Л. (1990). Религиозность Пушкина. Пушкин в русской философской критике. Москва, 380-96.

15. Galkina, E. S. (2002). The Secrets of the Russian Khaghanate. Moscow: Veche. [Галкина, Е. С. (2002). Тайны Русского Каганата. Москва: Вече.]

16. Ganichev, V. N. (n.d.). Vostok and Russia. Orthodox Christianity and Islam.[Ганичев, В. Н. Восток и Россия, Православие и Ислам. Oпыт взаимодействия культур.] Retrieved from http://ganichev.voskres.ru/dp34.htm.

17. Golden, P. B. (1995). Rus. In Encyclopedia Islamica $2^{\text {nd }}$ Ed, Leiden: Brill, 8, 618-29.

18. Greenleaf, M. (1994). Pushkin and Romantic Fashion. Stanford, CA: Stanford University Press.

19. Hokanson, K. E. (1994). Empire of the Imagination: Orientalism and the Construction of Russian National identity in Pushkin, Marinskii, Lermontov and Tolstoi. PhD Thesis, Stanford University, Stanford, CA.

20. Hokanson, K. E. (1994). Literary Imperialism, Narodnost' and Pushkin's invention of the Caucasus. The Russian Review, 53, 336352.

21. Ivanov, V. V. (1985). Oriental motives and styles in the Western poetry. Oriental Motives. Petry and poems. Moscow, 424-70.[Иванов, В. В. (1985). Темы и стили Востока в поэзии Запада. Восточные мотивы. Стихотворения и поэмы. Москва, 424-70.]

22. Jauss, H. R. (1982). Toward an Aesthetic of Reception. (Trans. Timothy Bahti). Minneapolis: U of Minnesota.

23. Kashtaleva, K.S. (1928). The sources of Pushkin's "Imitations of the Quran." Notes of the Orientalist Scholars of the Asian Museum of the USSR Academy of Science, V.L.N. 8, 157-62. [Кашталева, K. C. (1928). "Подражания Корану" Пушкина и их первоисточник. Записки коллегии востоковедов при Азиатском музее Академии наук СССР, Серия В. Л., N 8, 157-62.]

24. Khan, R. (n.d.). Qays ibn al-Mulawwah (working paper). Trinity University.

25. Kilito, A. (2001). The Author and His Doubles: Essays on Classical Arabic Culture. Syracuse, NY: Syracuse University Press.

26. Kraval, L.A. (1997). Pushkin's Drawings as a Graphic Diary. Moscow: Nasledia. [Краваль, Л. А. (1997). Рисунки Пушкина как графический дневник. Москва: Наследие.] 
27. Kubacheva, V. N. (1962). Oriental Novels in the Russian Literature of $18^{\text {th }}-19^{\text {th }}$ centuries. V.5, 295-315. [Кубачева B.Н. (1962). "Восточная" повесть в русской литературе ХVIII-начала ХІХ века. сб. 5. Москва-Ленинград. 295-315.]

28. Kutik, I. (2008). The Myth about the Golden Age of the Russian Poetry. [Кутик, И. (2008). Миф о Золотом Веке Русской Поэзии.] Retrieved from http://max.mmlc.northwestern.edu/ mdenner/Demo/index.html.

29. Layton, S. (2000). Russian Literature and Empire: Conquest of the Caucasus from Pushkin to Tolstoy. Cambridge Studies in Russian Literature. Cambridge: Cambridge University Press.

30. Lotman, Y. M. (2002). The Poetics of the Everyday Behavior in the Russian Culture of the $18^{\text {th }}$ Century. History and Typology of the Russian Culture. St. Petersburg: Isskustvo. [Лотман, Ю. М. (2002). Поэтика бытового поведения в русской культуре XVIII века. История и типология русской культуры. Санкт-Петербург: Исскуство.]

31. Macfie, A. L. (2000). Orientalism: A Reader. New York, NY: New York Press.

32. Mandelshtam, O. (1990). Compositions. Moscow, V.2. [Мандельштам, О. (1990), Сочинения. Москва, т. 2.

33. Masterlinck, M., Quotes. (2015). Retrieved from http://www.quotes.net/quote/15380

34. Montgomery, J. E. (2000). Ibn Faḍlān and the Rūsiyyah. Journal of Arabic and Islamic Studies, 3, 1-25.

35. Motyl, V. (1970). The White Sun of the Desert. USSR: Mosfilm.

36. Naturalized texts/Textes naturalisés, Translations, Adaptations, Influences (2004). Conference, UCLA Clark Library, Los Angeles, CA,

37. Navoi, A. (1990). Leili and Mejnun. Tashkent: Uzbekistan Communist Party Publishing. [Навои, А. (1990). Лейли и Меджнун. Ташкент: Издательство ЦК Компартии Узбекистана.

38. Nepomnyashchiy, C.T., Svobodniy, N., \& Trigos, L.A. (Eds). (2006). Under the Sky of My Africa: Alexander Pushkin and Blackness. Evanston, IL: Northwestern University Press.

39. Noeldeke, T.H. (1890). Delectus. Berolini: H. Reuther.

40. Pushkin, A. S. (1999). The Complete Collection of Works in 10 Volumes. Russian Virtual Library. [Пушкин, А. С. (1999). Полное собрание сочинений в 10 томах. Русская Виртуальная Библиотека.] Retrieved from http://www.rvb.ru/pushkin/toc.htm.

41. Pushkin, the Spiritual Father of Russian Poetry. (2009). Proceedings of International Association of Universities (IAU) annual conference, 
Lebanon: Notre Dame University.

42. Said, E. W. (1978), Orientalism, New York, NY: Pantheon.

43. Schimmelpenninck, O. D. (2010). Russian orientalism: Asia in the Russian mind from Peter the Great to the emigration. New Haven: Yale University Press.

44. Sugarenko, E. (2003). Pushkin Knew the Quran in Details. Tatar World, 3. [Сугаренко, Е. (2003). Пушкин знал Коран досконально. Татарский Мир, 3.] Retrieved from http://www.tatworld.ru/article.shtml?article=239\&section=0\&headin $\mathrm{g}=0$.

45. The Anthology of the Classical Arabic Poetry. (n.d.). Retrieved from http://www.al-akawati.net/arabic/arabpers/poemindex.asp.

46. The Holy Quran. (n.d.). Retrieved from http://quran-online.net/.

47. Tyutchev, F. (1996). Selected Works. World Library of Poetry. Rostovon-Don: Phoenix. [Тютчев, Ф. (1996). Избранное. Всемирная библиотека поэзии. Ростов-на-Дону: Феникс.]

48. Ueland, C. (1992). Viacheslav Ivanov's Pushkin. In Gasparov, B. Hughes, RP., \& Paperno, I. (Eds.). Cultural mythologies of Russian modernism: from the golden age to the silver age. Los Angeles, CA: University of California Press, 337-355.

49. Wachtel, A. (2014). From the Ends to the Beginning: A Bilingual Web Anthology of the Russian Verse. Retrieved from http://www.russianpoetry.net.

50. Yakobson, R. (1985). Selected Works. Moscow: Progress. [Якобсон, P. (1985). Избранные работы. Москва: Прогресс.]

51. Yevtushenko, E. (1988). A Prayer before a Poem. In Krementsov, L. P. (Ed.). Russian Soviet Poetry. Leningrad: Prosveshchenie. [Евтушенко, Е. (1988). Молитва перед поэмой. В Кременцов, Л.П. (Ред). Русская советская поэзия. Ленинград: Просвещение.]

52. Zhirmunsky, V. M. (1937). Pushkin and the Western Literatures. Vremennik of Pushkin's Commission, 3, Moscow-Leningrad. [Жирмунский, В. М. (1937). Пушкин и западные литературы. Временник Пушкинской Коммиссии, 3, М.- Л.] 